\title{
Identification of Bacteria that Contribute to Imp Degradation in Horse Mackerel
}

Hiroko Seki and Naoko Hamada-Sato*

Course of Safety Management in Food Supply Chain, Tokyo University of Marine Science and Technology, Tokyo, Japan

\begin{abstract}
Inosinic acid (inosine monophosphate, or IMP) is a taste component of fish that is broken down by an IMP-degrading enzyme (IMPase), impacting flavor. To measure IMPase activity, the enzyme is extracted as a solution from homogenized fish flesh, the IMP is then degraded by the enzyme, and the production of phosphoric acid from IMP is quantified. However, the degradation of IMP by bacteria that can be present in fish muscle could potentially affect the quantitation of endogenous IMPase activity. In this study, we isolated two bacterial strains from the enzyme solution obtained from horse mackerel and investigated their ability to degrade IMP. The isolates were identified as Pseudomonas fragi and either Pseudomonas veronii or Pseudomonas extremaustralis, as determined by 16S rDNA analysis. Of the two isolates, only P. fragi was found to be able to degrade IMP. Furthermore, the influence of the bacteria on the detection of IMPase activity was only seen when the reaction time was extended beyond $24 \mathrm{~h}$.
\end{abstract}

Keywords: Inosinic acid (IMP); IMPase; Bacteria; Enzyme activity; Enzyme reaction time

\section{Introduction}

Inosinic acid (IMP) is an important taste component of fish [1]. IMP is produced by the postmortem degradation of ATP as follows:

\section{$\mathrm{ATP} \rightarrow \mathrm{ADP} \rightarrow \mathrm{AMP} \rightarrow \mathrm{IMP} \rightarrow \mathrm{HxR} \rightarrow \mathrm{Hx}$}

The degradation from ATP to IMP proceeds relatively early [2] and IMP accumulates in fish muscle. Because IMP is broken down into $\mathrm{HxR}$ (inosine) and $\mathrm{Hx}$ (hypoxanthine), which are non-taste components, by IMPase over time, the suppression of IMPase activity can help maintain taste [3]. It has been reported that there are multiple sources of IMPase [4] and the type and the quantity of IMPase vary with the type of fish. Therefore, the examination of multiple IMPases is necessary to determine suitable conditions for the maintenance of the taste component in fish varieties by the suppression of IMPase activity.

In general, IMPase (produced by the fish) is primarily responsible for IMP degradation. IMPase activity is typically measured following extraction from homogenized fish flesh as an enzyme solution. IMPase activity is determined by measuring the production of phosphoric acid when a finite quantity of IMP is added and the reaction is incubated under various conditions [3-9]. However, it has been reported that IMP can also be degraded by bacteria in Japanese oysters and chicken [10-12]. Thus, bacterial contamination of fish may influence the measurement of endogenous IMPase activity. We performed a study on the maintenance of IMP in horse mackerel muscle, and it was necessary to measure IMPase activity precisely. However, the possibility that IMP is degraded by a factor other than the endogenous IMPase was suggested. Bacteria are not normally present in fish meat muscle, thus bacterial contamination of the IMPase reaction is probably introduced via the experimental setup or the internal organs of the fish. Because bacteria grow exponentially, longer reaction times will result in the acceleration of the reaction rate as the bacterial population increases. This complicates the ability to measure IMPase activity definitively and reliably.

In this study, we examined an enzyme extract to confirm whether bacteria are present in fish muscle. Isolated bacteria were cultured and identified. Finally, we assessed the ability of the bacteria to degrade IMP, thus confirming that bacteria can affect the measurement of
IMPase activity from fish. Furthermore, we determined the enzymatic reaction time to optimally measure IMPase activity without influence from bacterial contamination.

\section{Materials and Methods}

\section{Sample preparation}

Horse mackerel (Chiba-grown) were purchased at a retail store in Tokyo. IMPase was extracted from fish samples as follows. Horse mackerel dorsal meat was collected and homogenized in three volumes of ultra-pure water. The homogenate was dialyzed against ultra-pure water for 2 days, after which the dialysate was filtered (No. 1; Advantec Co., Ltd., Tokyo, Japan) and diluted twice at $10^{\circ} \mathrm{C}$ (enzyme solution). Aliquots were also filter-sterilized $(0.2 \mu \mathrm{m}$; Advantec Co., Ltd., Tokyo, Japan) for additional analyses.

\section{Assessment of IMPase activity and reaction time}

IMPase activity was measured using a standard reaction mixture that consisted of buffer ( $28 \mathrm{mM}$ maleic acid/ Tris/NaOH, pH 6.5), 1.6 $\mathrm{mM}$ IMP, and $12.5 \%$ of the enzyme solution, filter-sterilized enzyme solution, or ultra-pure water (as without enzyme) in a total volume of $4 \mathrm{~mL}$. The reaction mixture was incubated at $20^{\circ} \mathrm{C}$ for $0-48 \mathrm{~h}$, and the reaction was stopped at regular intervals by the addition of $10 \%$ perchloric acid (final concentration, 3.3\%). The precipitate was separated by centrifugation at $13,040 \times g$ for $10 \mathrm{~min}$, and the level of free phosphoric acid was determined using the molybdenum blue method [13]. The amount of phosphoric acid was thought to reflect the level of enzyme activity.

*Corresponding author: Naoko Hamada-Sato, Course of Safety Management in Food Supply Chain Tokyo University of Marine Science and Technology, 4-5-7, Konan, Minato-ku, Tokyo, 108-8477, Japan, Tel: +81-3-5463-0389; Fax: +81-35463-0389; E-mail: hsnaoko@kaiyodai.ac.jp

Received August 01, 2014; Accepted September 04, 2014; Published September 11,2014

Citation: Seki H, Hamada-Sato N (2014) Identification of Bacteria that Contribute to Imp Degradation in Horse Mackerel. J Food Process Technol 5: 363. doi:10.4172/2157-7110.1000363

Copyright: (c) 2014 Seki H, et al. This is an open-access article distributed under the terms of the Creative Commons Attribution License, which permits unrestricted use, distribution, and reproduction in any medium, provided the original author and source are credited. 


\section{Examination of the bacterial flora in the enzyme solution}

The presence and number of bacteria in the enzyme solution was determined by standard plate count. An aliquot $(0.1 \mathrm{~mL})$ of the enzyme solution was spread on plates with a standard agar medium (Pearl Core; Eiken Chemical Co., LTD), cultured at $20^{\circ} \mathrm{C}$ for $48 \mathrm{~h}$. The bacterial flora present in the enzyme solution consisted of two predominant and distinct colony types. These two bacteria were sub-cultured to purity and identified by sequencing the 16S rRNA gene. Sequencing was performed by TechnoSuruga Laboratory Co., Ltd. (16S r-DNA-500 service; Shizuoka, Japan). Cells were lysed with achromopeptidase (Wako Pure Chemical Industries, Ltd., Osaka, Japan) to obtain a DNA template. PrimeSTAR HS DNA Polymerase (Takara Bio Inc., Shiga, Japan) and the BigDye Terminator v3.1 Cycle Sequencing Kit (Applied Biosystems, Foster City, CA, USA) were used for the sequencing reactions. Base sequence determination was accomplished with ChromasPro 1.7 (Technelysium Pty Ltd., Tewantin, AUS) and Aporon 2.0 (TechnoSuruga Laboratory Co., Ltd.) was used for sequence analysis. Aporon DB-BA9.0 (TechnoSuruga Laboratory Co., Ltd.) was used to make comparisons to the International Nucleotide Sequence Databases (GenBank/DDBJ/EMBL).

\section{IMP degradation by bacteria isolated from the enzyme solution}

The two bacterial flora that were isolated from the enzyme solution were sub-cultured in liquid medium (Standard I Nutrient Broth containing of $15 \mathrm{~g}$ Bacto peptone, $3 \mathrm{~g}$ Bacto malt extract, $6 \mathrm{~g} \mathrm{NaCl}$, and $1 \mathrm{~g}$ glucose in distilled water to $1 \mathrm{~L}$; Merck Ltd, Japan [26]) at $20^{\circ} \mathrm{C}$ for $24 \mathrm{~h}$. After separation by centrifugation $(10,000 \times \mathrm{g}$, for $10 \mathrm{~min})$, bacteria were washed and suspended in $1 \mathrm{~mL}$ of $0.9 \%$ saline (bacterial solution). A $0.1 \mathrm{~mL}$ aliquot of the bacterial solution was cultured at $20^{\circ} \mathrm{C}$ for $24 \mathrm{~h}$. The bacterial solution was added to the filter-sterilized standard reaction mixture described in Assessment of IMPase activity and reaction time. The reaction mixture was incubated at $20^{\circ} \mathrm{C}$ for 0 to $48 \mathrm{~h}$, and the reaction was stopped at $0 \mathrm{~h}, 24 \mathrm{~h}, 48 \mathrm{~h}$ by the addition of $10 \%$ perchloric acid (final concentration, $3.3 \%$ ). The level of free phosphoric acid was determined using the molybdenum blue method [13]. At the same time, $0.1 \mathrm{~mL}$ of the bacteria solution was plated on standard agar medium, incubated at $35^{\circ} \mathrm{C}$ for $24 \mathrm{~h}$, and the CFUs were counted.

\section{Statistical analysis}

Data from the level of free phosphoric acid were subjected to oneway analysis of variance using the least significant difference method $(p<0.05)$. Data from regression lines were subjected to analysis of covariance using the least significant difference method $(\mathrm{p}<0.05)$.

\section{Results}

\section{Assessment of IMPase activity in horse mackerel over time}

To quantify the level of IMPase activity in horse mackerel, the production of phosphoric acid was measured over time (Figure 1). IMPase activity levels of $0.54 \mathrm{mg} / \mathrm{L}$ and $19 \mathrm{mg} / \mathrm{L}$ were observed at 3 $\mathrm{h}$ and $48 \mathrm{~h}$, respectively, revealing that IMPase activity accelerated as the reaction time lengthened $(\mathrm{p}<0.05)$. We presented an approximate expression to show the relationship of enzyme activity and reaction time as a multinomial expression (a quadratic equation) and confirmed the correlation. The multinomial expression and correlation was $y=0.0068 x^{2}+0.071 x+0.71, R^{2}=0.994$. High correlation was confirmed in a quadratic equation.
To determine if bacteria present in the enzyme solution contributed to the detected IMPase activity, filter-sterilized aliquots of the enzyme solution were tested alongside unfiltered aliquots (Figure 2). In addition, a negative control without the enzyme solution was included to determine if any IMP degradation was due to bacterial contamination during the assay setup. Here, the production of phosphoric acid was detected in both the filter-sterilized and unfiltered enzyme solutions over time $(p<0.05)$; however, the amount of phosphoric acid did not increase in the negative control. Therefore, IMP degradation was not due to contamination during the assay setup. In addition, the approximate expression and correlation was $\mathrm{y}=0.0068 \mathrm{x}^{2}+0.071 \mathrm{x}+$ $0.071, \mathrm{R}^{2}=0.9994$. When unfiltered enzyme solution was used, the reaction rate was found to increase over time. However, when the enzyme solution was filter-sterilized prior to the reaction, the reaction rate remained constant and had a tendency to reach saturation by $24 \mathrm{~h}$. This suggests that IMP was degraded by an additional enzyme activity, which was probably produced by bacteria present in the unfiltered enzyme solution.

\section{Isolation and identification of the bacterial flora present in the enzyme solution}

To determine the presence of bacteria in the enzyme solution, an aliquot was plated on a standard agar medium. After incubation, we confirmed the presence of bacteria. On the basis of colony morphology, there appeared to be two primary bacterial species present, designated HS-A and HS-B. Next, we identified the bacteria species based on the 16 rRNA gene sequence (Figures 3 and 4). HS-A was accordingly found to be most closely related to Pseudomonas fragi (percentage identity of $100 \%$ ) and HS-B was most closely related to either Pseudomonas veronii (100\%) or Pseudomonas extremaustralis (100\%).

\section{Degradation of IMP by the isolated bacteria}

To determine if the isolated bacteria were able to degrade IMP, suspensions of pure cultures were used in the IMPase assay. When we counted a number of bacteria in each bacteria solution, the number of standard plate count bacteria colonies confirmed on the standard agar medium showed $2.84 \times 10^{9} \mathrm{CFU} / \mathrm{mL}$ (HS-A) and $6.99 \times 10^{8} \mathrm{CFU} /$ $\mathrm{mL}$ (HS-B). We were able to confirm the existence of bacteria in each bacterial solution. Suspensions of HS-A $\left(2.84 \times 10^{9} \mathrm{CFU} / \mathrm{mL}\right)$ or HS-B $\left(6.99 \times 10^{8} \mathrm{CFU} / \mathrm{mL}\right)$ were added to the filter-sterilized reaction mixture and the ability on each bacteria to degrade IMP was examined (Table 1). The production of phosphoric acid by HS-A was detected (101 $\mathrm{mg} / \mathrm{L}$ at $24 \mathrm{~h}$ and $139 \mathrm{mg} / \mathrm{L}$ at $48 \mathrm{~h} ; \mathrm{p}<0.05$ ), indicating that it possesses some IMPase activity. Thus, it was found that IMP was degraded by HS-A over time. In contrast, the production of phosphoric acid was not detected by HS-B, indicating that it was not able to degrade IMP.

\section{Examination of the enzymatic reaction time on the IMPase activity measurement}

Since the presence of bacteria in the enzyme solution results in an acceleration of the reaction rate over time, it is important to limit the reaction time. It is necessary that we let IMPase degrade IMP until the product is detectable but cease the reaction before the bacterial influence is observed. Therefore, from Figure 2, we evaluated an approximate straight line until each time using a covariance analysis and we examined the enzymatic reaction time on the measurement of IMPase activity (Table 2). No significant difference was found by the slope and intercept on the linear approximate equation of the enzymatic reaction by using each filter-sterilized enzyme and unfiltered enzyme until $24 \mathrm{~h}$. However, a significant difference was found at $39 \mathrm{~h}$ and $48 \mathrm{~h}$. 
Citation: Seki H, Hamada-Sato N (2014) Identification of Bacteria that Contribute to Imp Degradation in Horse Mackerel. J Food Process Technol 5: 363. doi:10.4172/2157-7110.1000363

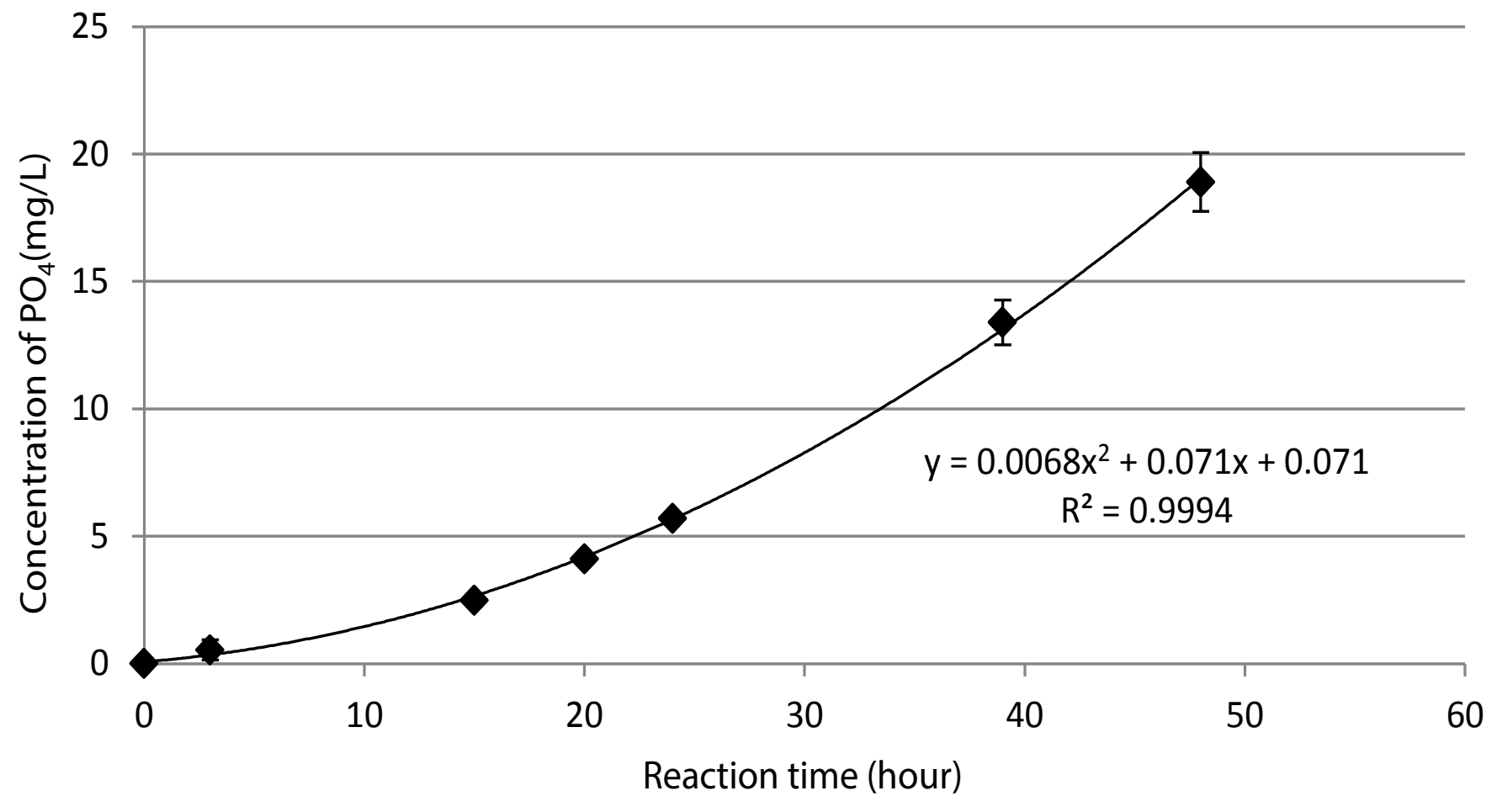

Figure 1: Change in the IMPase activity from horse mackerel over time (bars denote standard deviation of the mean; $n=3$ ). Mean values of relative activity indicate a significant $(p<0.05)$ difference at each hour using a one-way analysis of variance.

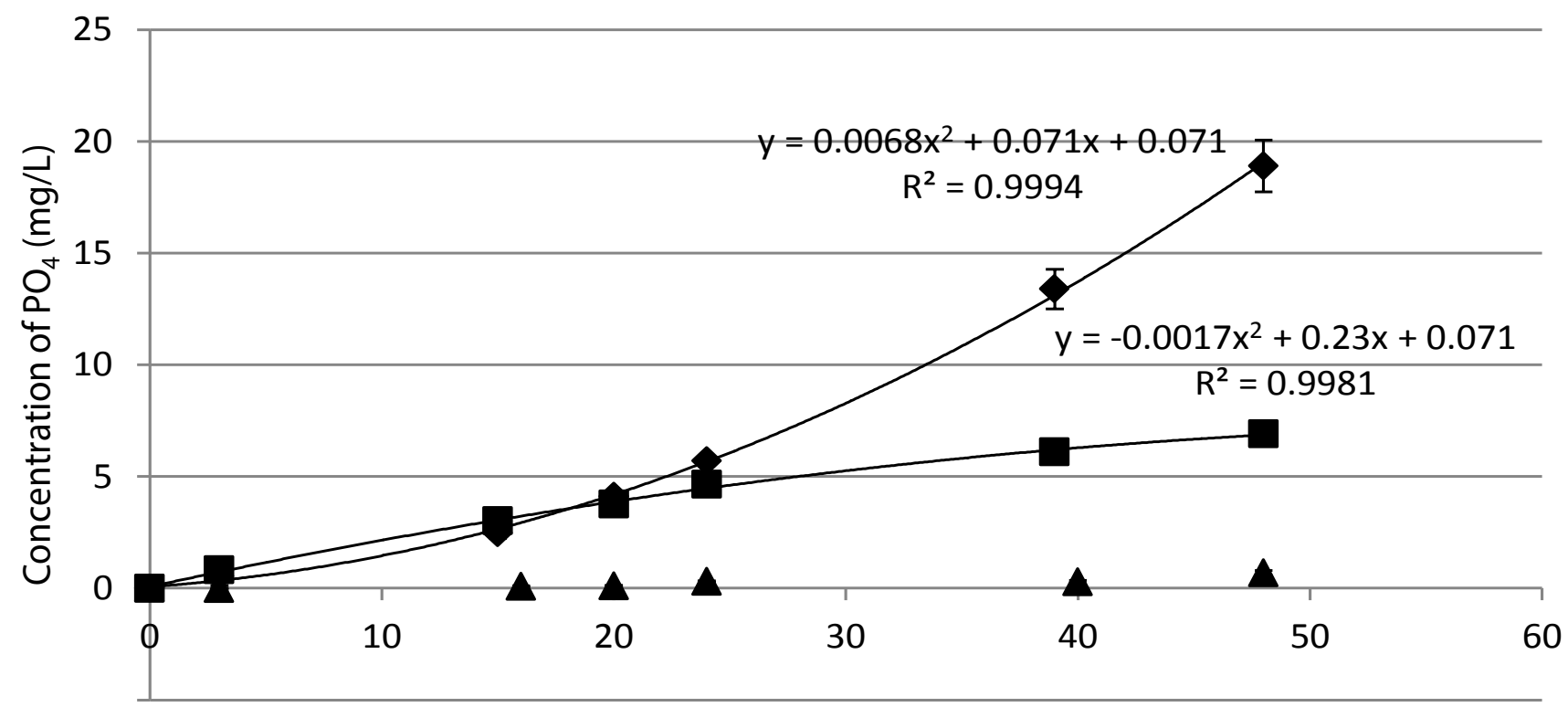

\section{Reaction time (hour)}

Figure 2: Changes in the IMPase activity of filter-sterilized enzyme solution (squares), unfiltered enzyme solution (diamonds), or negative control (triangles) over time (bars denote standard deviation of the mean; $n=3$ ). Mean values of relative activity indicate a significant $(p<0.05)$ difference at each hour. The enzyme solution contained $1.4 \times 102 \mathrm{CFU} / \mathrm{mL}$ at $24 \mathrm{~h}$ and $4.2 \times 102 \mathrm{CFU} / \mathrm{mL}$ at $48 \mathrm{~h}$. 


\begin{tabular}{|l|l|l|}
\hline Inoculated strain & \multicolumn{1}{|l|}{$\begin{array}{l}\text { Bacteria Count } \\
\text { (CFU/mL) }\end{array}$} & \multicolumn{2}{c|}{\begin{tabular}{l} 
Concentration of $\mathrm{PO}_{\mathbf{4}}$ (mg/L) \\
\hline $\begin{array}{l}\text { HS-A } \\
\text { (Pseudomonas fragi) }\end{array}$
\end{tabular}} & $2.84 \times 10^{9}$ & $101(3.8)$ \\
\hline $\begin{array}{l}\text { HS-B } \\
\text { (Pseudomonas veronii or Pseudomonas extremaustralis) }\end{array}$ & $6.99 \times 10^{8}$ & 0 \\
\hline
\end{tabular}

Table 1: Change in the amount of $\mathrm{PO}_{4}$ and bacterial count of reaction mixture. Mean value of three independent determinations ( $\mathrm{n}=3$ ). Standard deviations are indicated in parentheses. Mean values of the amount of $\mathrm{PO}_{4}$ indicate a significant $(\mathrm{p}<0.05)$ difference between $24 \mathrm{~h}$ and $48 \mathrm{~h}$ for $\mathrm{HS}-\mathrm{A}$.

\begin{tabular}{|c|c|c|c|c|}
\hline \multirow{2}{*}{ Time } & \multicolumn{2}{|c|}{ linear approximate equation } & \multicolumn{2}{|l|}{$\mathbf{P}$} \\
\hline & Not filtered & Filtered & Slope & Intercept \\
\hline $0-24 h$ & $y=0.22 x-0.21(0.96)$ & $y=0.18 x+0.13(1.0)$ & $0.207^{\star}$ & $0.684^{*}$ \\
\hline $0-39 h$ & $y=0.33 x-1.2(0.92)$ & $y=0.16 x+0.39(0.97)$ & $0.00868^{* *}$ & $-^{* * *}$ \\
\hline $0-48 \mathrm{~h}$ & $y=0.39 x-1.9(0.94)$ & $y=0.14 x+0.57(0.97)$ & $0.000289^{* *}$ & $-* *$ \\
\hline
\end{tabular}

Table 2: The comparison of linear approximate equation on the enzymatic reaction until each time () shows coefficient of correlation, * $p>0.05$; not significant, ${ }^{* *} p<0.05$; significant, ${ }^{* * *}$ When significant difference was not confirmed in slope, the intercept was not examined.

\section{Discussion}

\section{The degradation of IMP due to bacteria}

An acceleration of the reaction rate was observed when the activity of IMPase was measured in extracts of horse mackerel, indicating the presence of an additional factor that contributes to IMP degradation. Typically, an enzymatic reaction will progress in a linear manner with a constant reaction rate. As the substrate is depleted, the reaction rate decreases [14]. Therefore, if it is only an enzymatic reaction, the reaction rate does not increase exponentially. Such an increase is a tendency that is generally observed in bacteria $[15,16]$, and thus it is likely that bacteria present in the reaction may also degrade IMP.

Previously, the degradation of IMP due to bacteria was demonstrated when the addition of loramphenicol (CP), an antimicrobial, prevented the acceleration of the reaction rate of ATP degradation in oyster $[11,12]$ or prawn [17]. ATP degradation was increasingly rapid in the absence of $\mathrm{CP}$ compared with the presence of $\mathrm{CP}$ after 4 days on oysters or prawns. In addition, the production of $\mathrm{HxR}$ and $\mathrm{Hx}$ decreased when cod mince was sterilized [18]. On the basis of these reports, it was suggested that IMP was degraded by bacteria but the source of the bacteria-either bacteria present in the muscles or contamination during assay setup-was not confirmed.

In this study, the degradation of IMP was attributed to the presence of bacteria in the enzyme extract from horse mackerel, not contamination during assay setup (Figure 2), thus revealing that bacteria are present in fish muscle. Although it is believed that the bacteria do not exist in the muscle of fish originally, it has been reported that bacteria can be introduced by physical factors such as the friction between fish in the fish catch, transportation, and catch landing [19]. In addition, it is possible that bacteria invade fish muscle from the internal organs and skin after death. When we investigated the varieties of bacteria present in horse mackerel, we found a number of Vibrio spp. and Pseudomonas spp. [20]. Pseudomonas spp. were identified among the bacterial flora that were extracted with the enzyme solution in this study (Figures 3 and 4 ). While the production of inosine nucleosidase by Psuedomonas spp. has been reported previously [21], there are no reports regarding the degradation of IMP by Psuedomonas spp.

The results of the phylogenetic analysis revealed that HS-A was most likely $P$. fragi and HS-B was either $P$. veronii or $P$. extremaustralis. Furthermore, it was found that HS-A had the ability to degrade IMP but
HS-B did not (Table 1). It is possible that $\mathrm{PO}_{4}$ was not detected when HS-B was added because of the difference in the bacterial numbers between reactions containing HS-A and HS-B. However, the IMPase activity assay was sensitive to $\mathrm{PO}_{4}$ concentrations as low as $1 \mathrm{mg} / \mathrm{L}$, the detection limit of this method. If HS-B had the ability to degrade IMP, IMP would have been degraded and $\mathrm{PO}_{4}$ would likely have been detected. Thus, we concluded that HS-B is unable to degrade IMP. As shown in Figure 2, when an unfiltered enzyme solution was used, the amount of $\mathrm{PO}_{4}$ at $48 \mathrm{~h}$ was 3-4 times that at $24 \mathrm{~h}$. However, the amount of $\mathrm{PO}_{4}$ at $24 \mathrm{~h}$ and $48 \mathrm{~h}$ were mostly the same as shown in Table 1 . The amount of $\mathrm{PO}_{4}$ shown in Figure 2 was lower than that shown in Table 1 because of the difference in the bacterial count. To confirm whether the bacteria degraded IMP, we used cultures that were sufficiently grown. Therefore, we considered that, because the amount of IMP was low relative to the bacterial count, the degradation of IMP at $48 \mathrm{~h}$ was saturated (Table 1). Confirmation that the upward deflection seen in Figure 2 is indeed attributable to bacterial activity will be necessary in the future.

$P$. fragi is one of the main bacterial flora in cooled and refrigerated edible meat and there are reports that $P$. fragi degrades protein in chicken [22], rabbit [23], and beef [24]. Accordingly, a protease that is responsible for hydrolyzing peptide bonds was isolated from $P$. fragi [24]. It has been reported that myosin was hydrolyzed by an enzyme isolated from $P$. fragi [23]. Previously, a bacterial protease has also been shown to have IMP degradation activity. The amount of free amino acid increased but the amount of sodium inosinate decreased when a bacterial protease was added to dried bonito [25,26]. Therefore, it is thought that IMP degradation by $P$. fragi was due to a protease.

\section{Examination of the enzymatic reaction time on the IMPase activity measurement}

As no significant difference was found by the slope and intercept on the linear approximate equation of the enzymatic reaction using filter-sterilized and unfiltered enzyme solution until $24 \mathrm{~h}$, we can disregard the bacterial influence for time points prior to $24 \mathrm{~h}$. However, as a significant difference was found at $39 \mathrm{~h}$ and $48 \mathrm{~h}$, it was concluded that bacterial growth influenced the measurement of IMP degradation at longer incubation times. Therefore, sterilization of the enzyme solution is not required by the time that IMPase activity is detectable but it is desirable to stop the reaction by $24 \mathrm{~h}$. In addition, a tendency to be saturated $24 \mathrm{~h}$ later was seen in the enzymatic reaction with the 

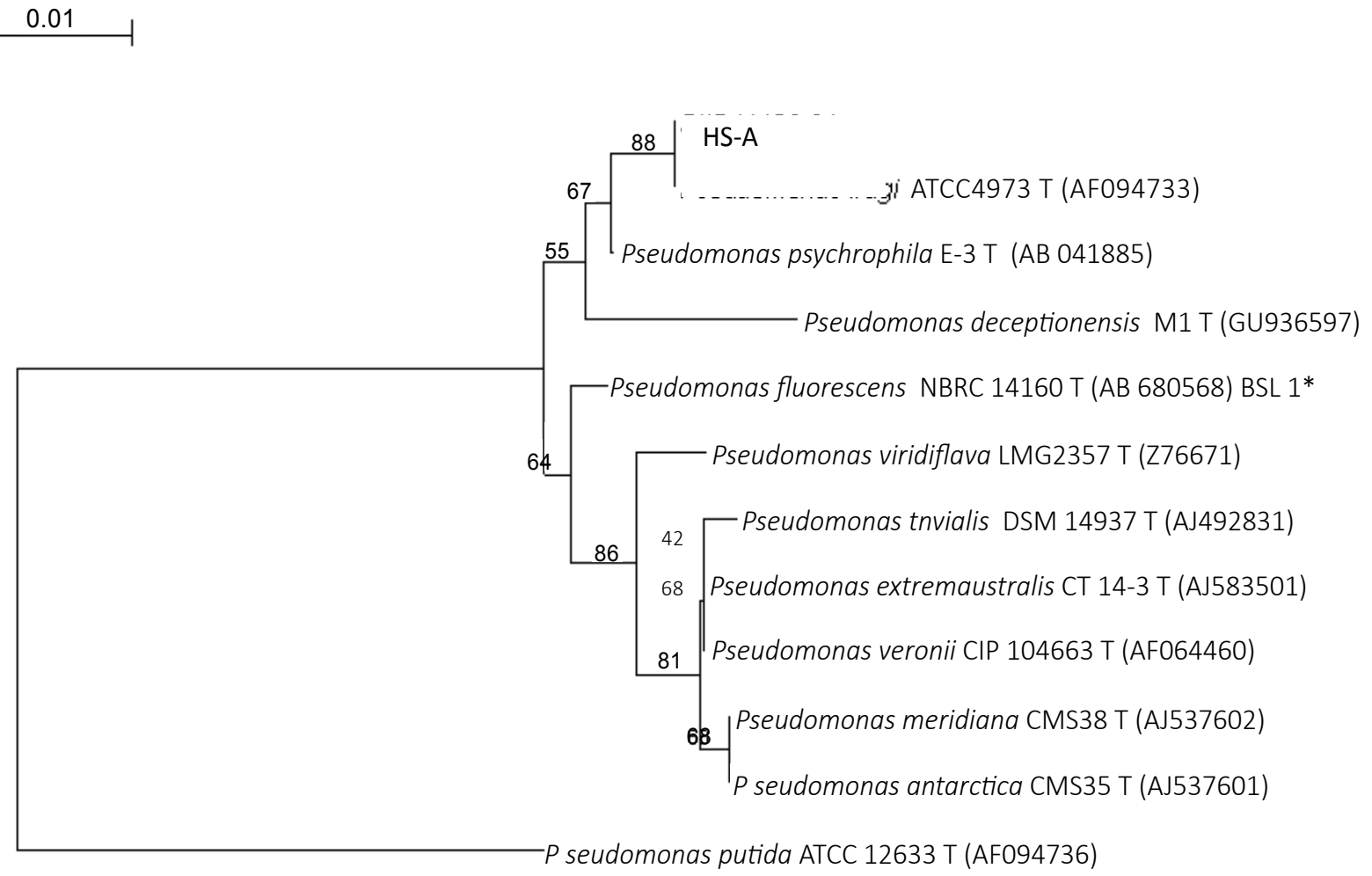

DNA base sequence on HS-A

GAGTTTGATCCTGGCTCAG

ATTGAACGCTGGCGGCAGGCCTAACACATGCAAGTCGAGCGGTAGAGAGAAG CTTGCTTCTCTTGAGAGCGGCGGACGGGTGAGTAATACCTAGGAATCTGCCTGA TAGTGGGGGATAACGTTCGGAAACGGACGCTAATACCGCATACGTCCTACGGGA GAAAGCAGGGGACCTTCGGGCCTTGCGCTATCAGATGAGCCTAGGTCGGATTA GCTAGTTGGTGAGGTAATGGCTCACCAAGGCTACGATCCGTAACTGGTCTGAGA GGATGATCAGTCACACTGGAACTGAGACACGGTCCAGACTCCTACGGGAGGCA GCAGTGGGGAATATTGGACAATGGGCGAAAGCCTGATCCAGCCATGCCGCGTG TGTGAAGAAGGTCTTCGGATTGTAAAGCACTTTAAGTTGGGAGGAAGGGCATT AACCTAATACGTTGGTGTCTTGACGTTACCGACAGAATAAGCACCGGCTAACTCT GTGC CAGCAGCCGCGGTAATAC

Figure 3: Phylogenetic tree based on the 16s rRNA gene sequence of HS-A. Horizontal bars denote unit distance. The scale bar is indicated as a line in the lower left. Bootstrap values (\%) are shown on the internal branches. "T" of the end of the strain name indicates a type strain. 


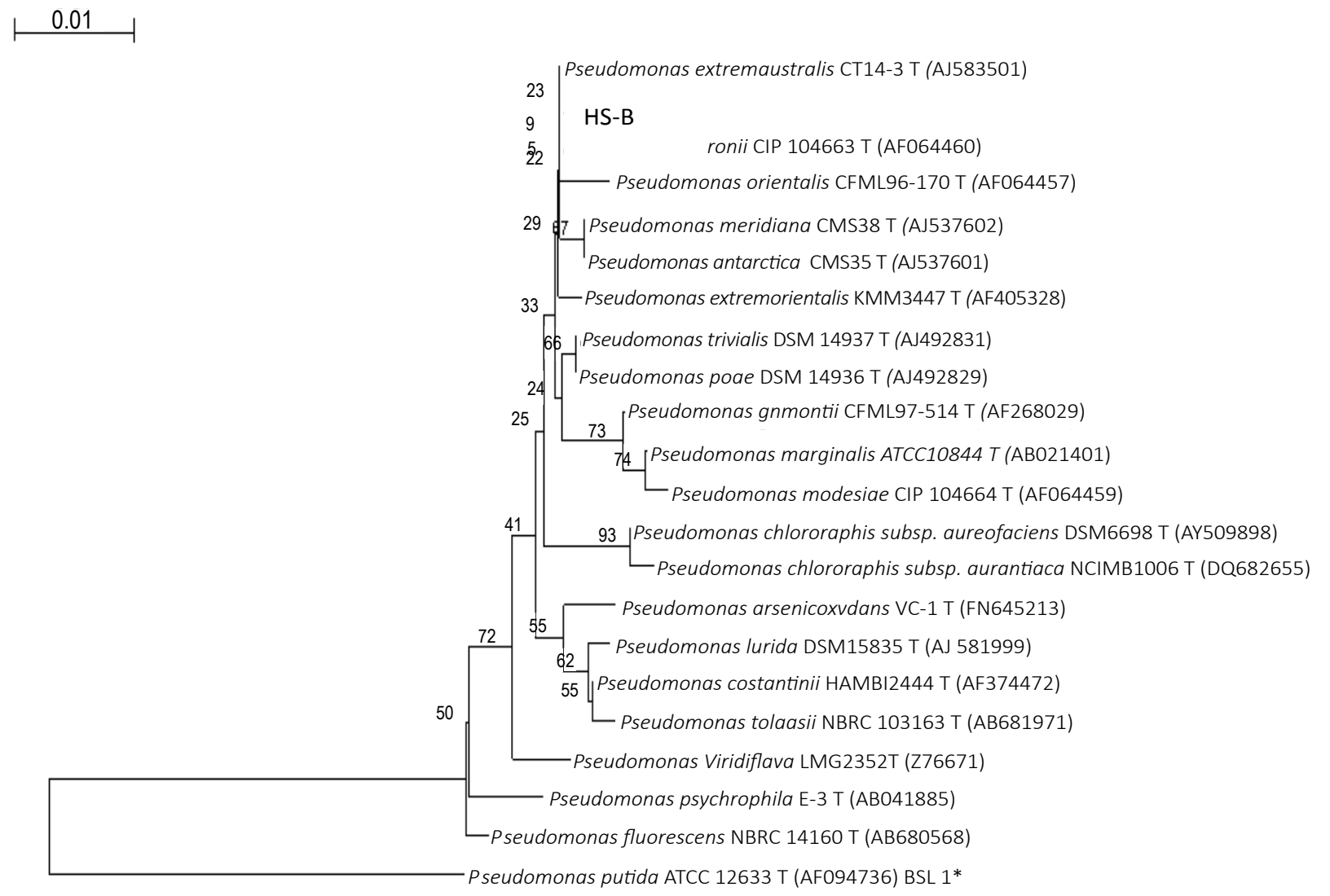

DNA base sequence on HS-B

GAGTTTGATCCTGGCTCAG

ATTGAACGCTGGCGGCAGGCCTAACACATGCAAGTCGAGCGGTAGAGAGAAG CTTGCTTCTCTTGAGAGCGGCGGACGGGTGAGTAATGCCTAGGAATCTGCCTG GTAGTGGGGGATAACGTTCGGAAACGGACGCTAATACCGCATACGTCCTACGGG AGAAAGCAGGGGACCTTCGGGCCTTGCGCTATCAGATGAGCCTAGGTCGGATT AGCTAGTTGGTGAGGTAATGGCTCACCAAGGCGACGATCCGTAACTGGTCTGA GAGGATGATCAGTCACACTGGAACTGAGACACGGTCCAGACTCCTACGGGAGG CAGCAGTGGGGAATATTGGACAATGGGCGAAAGCCTGATCCAGCCATGCCGCG TGTGTGAAGAAGGTCTTCGGATTGTAAAGCACTTTAAGTTGGGAGGAAGGGCA GTTACCTAATACGTGATTGTTTTGACGTTACCGACAGAATAAGCACCGGCTAACT CTGTGC

\section{CAGCAGCCGCGGTAATAC}

Figure 4: Phylogenetic tree based on the 16s rRNA gene sequence of HS-B. Horizontal bars denote unit distance. The scale bar is indicated as a line in the lower left. Bootstrap values (\%) are shown on the internal branches. "T" of the end of the strain name indicates a type strain. 
Citation: Seki H, Hamada-Sato N (2014) Identification of Bacteria that Contribute to Imp Degradation in Horse Mackerel. J Food Process Technol 5: 363. doi:10.4172/2157-7110.1000363

filter-sterilized enzyme solution. When the reaction time was extended past $24 \mathrm{~h}$, it is necessary to sterilize the enzyme solution. In the present study, we examined IMPase activity in only a single species, the horse mackerel, and therefore, in the future, it will be necessary to investigate IMPase activity in other fish species.

\section{Conclusion}

In this study, we isolated, cultured, and identified bacteria from fish muscle. We assessed the ability of the bacteria to degrade IMP and determined the enzymatic reaction time to optimally measure IMPase activity in the absence of any significant influence from bacterial contamination. Pseudomonas fragi and Pseudomonas veronii or Pseudomonas extremaustralis were isolated from horse mackerel and Pseudomonas fragi was able to degrade IMP. In addition, no significant difference was found on the linear approximate equation of the enzymatic reaction using filter-sterilized and unfiltered enzyme solution until $24 \mathrm{~h}$. For the future analysis of IMPase activity, the use of a filter-sterilized enzyme solution would be advantageous to eliminate the possibility of confounding bacterial contamination. Furthermore, the activity becomes more consistent and robust when using a filtersterilized enzyme solution for $24 \mathrm{~h}$. However, we need to investigate the relationship between enzyme activity and reaction time because IMP degradation may become saturated when unfiltered enzyme solution is used. The measurement of IMPase activity is difficult because it can be affected by various factors. In addition to the method described here, there is a measurement method that uses an independently defined IMPase enzyme of known concentration, and also protein assays. These will possibly lead to future improvements in the measurement method.

\section{Acknowledgement}

The gene identification was supported by TechnoSuruga Laboratory Co., Ltd. (Shizuoka, Japan)

\section{References}

1. Maruji Y, Shimizu M, Hirata T, Murata M, Ando M, et al. (2010) Multiple taste functions of the umami substances in muscle extracts of yellowtail and bastard halibut. Fish Sci 76: 521-528

2. Srirangsan P, Hamada-Sato N, Kawai K, Watanabe M, Suzuki T (2010) Improvement of fish freshness determination method by the application of amorphous freeze-dried enzymes. J Agric Food Chem 58: 12456-12461.

3. Ooizumi T (2010) Effect of sodium chloride on inosine monophosphatase activity in fish meats and degradation of inosinic acid during drying process of salted fish meats. Research report of The Salt Science Research Foundation 2010: 133-140.

4. Tomioka K, Endo K (1984) K value-increasing rates and IMP-degrading activities in various fish muscles. Nippon suisan gakkaishi 50: 889-892.

5. Oba K, Niwa E (1993) The mode of inhibition by salts to two enzymes involved in IMP degradation in fish flesh. J Food Sci Technol 40: 583-588.

6. Obatake A, Doi T, Ono T (1988) Purification and properties of acid phosphomonoesterase from the dark muscle of common mackerel. Nippon suisan gakkaishi 54 : $283-288$
7. Nedachi K, Hirota N (1991) Changes in ATP related compounds and IMP degrading enzyme activity of New Zealand golden snapper. Nippon suisan gakkaishi 57: 329-335.

8. Tomioka K, Endo K (1988) Effect of sodium chloride and glycerine on activities of enzymes decomposing 5'-inosinic acid in fish muscle. Nippon suisan gakkaishi 54: 1947-1951.

9. Yada O, Tsuchimoto M, Wang Q, Apablaza PAG, Jabarsyah A, et al. (2001) Influence of interposition of pink muscle fiber into dorsal ordinary muscle on 5'IMP degrading activity in various fish species. Fish Sci 67: 948-955.

10. Hayashi M, Nakata K (2003) Effect of contaminating bacteria on the inosinic acid content of chicken meat. J Home Econ Jpn 54: 441-448.

11. Yokoyama Y, Azuma Y, Kawai F, Kanamori M, Sakagushi M (1995) ATPbreakdown by endogenous enzymes in the mantle of oyster during storage. Ann Report Interdiscipl Res Inst Environ Sci 14: 73-77.

12. Yokoyama Y, Azuma Y, Kawai F, Kanamori M, Sakaguchi M (1996) Postmortem changes of ATP and its related compounds in oyster tissues in the presence of antibiotic chloramphenicol. Fish Sci 62: 312-316.

13. The Salt Industry Center of Japan (2007) Analysis method of the salt: The Salt Industry Center of Japan, Tokyo, The Salt Industry Center of Japan.

14. Zeffren E, Hall PL (1977) The study of enzyme mechanisms, trans. Tabushi, Tokyo, University of Tokyo Press.

15. Koga K (2004) Evaluation of the growth activity of microbial colonies on solid medium using calorimetry. Netsu Sokutei 31: 117-124.

16. Satsuta K, Terada A, Inubushi T (2007) Syokuhin eiseigaku neo esuka, Tokyo, Dobun-syoin.

17. Matsumoto M, Yamanaka H (1991) Influences of antibiotics chloramphenico on post-mortem biochemical changes in the muscle of Kuruma Prawn during Storage. Nippon suisan gakkaishi 57: 2291-2297.

18. Muyonga JH, Regenstein JM (1997) Bacterial and autolytic changes in wate retention and adenosine nucleotides of cod mince. J Food Sci 62: 1139-1141.

19. loka H (1993) Raw material characteristics of masscatch redmeat fish. Bacterial contamination at the period of high freshness. Bulletin of Shimane Prefectural Fisheries Experiment Station 1991: 91-94.

20. Satomi M (2002) Reclassification in the bacteria group letting fishery products decay. Bulletin of the National Research Institute of Fisheries Science, Fisheries Research Agency 28.

21. Surette ME, Gill TA, LeBlanc PJ (1988) Biochemical basis of postmortem nucleotide catabolism in cod (Gadus morhua) and its relationship to spoilage. $J$ Agric Food Chem 36: 19-22.

22. Livera WCD, Miura H, Mikami M (1981) Action of Pseudomonas fragi on the myofibrillar proteins of chicken muscle. Research Bulletin of Obihiro Zootechnical University. Series I 12: 207-216.

23. Porzio MA, Pearson AM (1980) Degradation of myofibrils and formation of premeromyosin by a neutral protease produced by Pseudomonas fragi. Food Chem. 5: 195-199.

24. Bala K, Marshall RT, Stringer WC, Naumann HD (1979) Stability of sterile bee and beef extract to protease and lipase from Pseudomonas fragi. J. Food Sci. 44: 1294-1298.

25. Kawakubo A, Inoue T, Itai N, Ikeda H, Miyaoka M (2014) Sakanabushi and its manufacturing method, Japan Patent Kokai.

26. Merck (2014) Microbiology. Manual (12th Edition). 